\title{
Tackling precarious work in public supply chains: A comparison of local government procurement policies in Denmark, Germany and the UK
}

Karen Jaehrling, University of Duisburg-Essen, Germany

Mathew Johnson, University of Manchester, UK

Trine P. Larsen, University of Copenhagen, Denmark

Bjarke Refslund, Aalborg University, Copenhagen, Denmark

Damian Grimshaw, International Labour Organisation, Geneva

This is a pre-copyedited, author-produced PDF of an article accepted for publication in Work, Employment and Society following peer review. The original version is published as

Jaehrling, Karen; Johnson, Mathew; Larsen, Trine P.; Refslund, Bjarke; Grimshaw, Damian: 'Tackling precarious work in public supply chains: A comparison of local government procurement policies in Denmark, Germany and the UK'. Work, Employment and Society 2018, Vol 32 (3), pp. 546-563. Copyright @ The Author(s) 2018. DOI: 10.1177/0950017018758216. Reprinted by permission of SAGE Publications.

\begin{abstract}
Through a cross-national comparative study of local government "best practice cases" of socially responsible procurement in Denmark, Germany and the UK, this article critically examines the role of labour clauses in addressing issues of low wages and precarious work in public supply chains. It provides new insights on the negotiations and outcomes of labour clauses across different stages of the policy process, including implementation and monitoring. The analysis demonstrates the importance of pragmatic alliances of progressive local politicians, unions, and employers in ensuring that socially responsible procurement moves beyond rhetoric, along with supportive national and sectoral employment regimes. Labour clauses can compensate for weak systems of labour market regulation by setting higher standards for outsourced workers, while they play a complementary role in more regulated labour markets by levelling up wages and working conditions to prevailing collectively agreed standards.
\end{abstract}

\section{Key words}

Public procurement, precarious work, labour clause, public outsourcing, public services

Corresponding Author: Karen Jaehrling, University of Duisburg-Essen, Institut Arbeit und Qualifikation (IAQ), 47048 Duisburg. Email: karen.jaehrling@uni-due.de 


\section{Introduction}

The complex role of the state in directly shaping working conditions - through systems of labour market regulation, employment rights, and bi- and tripartite negotiations - has been spelled out extensively in the literature of industrial sociology and new economic sociology (e.g. Howell, 2016). More recently, increasing attention has been paid to the role of the state in indirectly shaping working conditions through the procurement of services from the private market, where the risk of precarious work can be high (Cunningham and James, 2009; Hermann and Flecker, 2012; Peters, 2012; Grimshaw et al., 2015).

In response, public sector bodies across diverse countries are increasingly confronted with expectations to adopt 'socially responsible procurement' practices which take into account noncommercial considerations such as environmental impact and the wages and working conditions of sub-contracted staff through the use of labour clauses ${ }^{1}$ (Keulemans and Walle, 2017). These 'marketcorrecting' references have been articulated clearly by local grassroots and trade union living wage campaigns for outsourced low-wage services (e.g. Wills, 2008). However, socially responsible procurement requires public sector bodies to balance their role as a regulatory authority charged with developing and maintaining functioning markets and securing positive outcomes for citizens with their role as a customer keen to maximise value for money (Jaehrling, 2015b; Grandia and Meehan, 2017).

Thus, despite the increasingly recognised potential of labour clauses to combat precarious work, their effectiveness strongly depends on how the seemingly contradictory goals of public bodies are balanced in practice. Researchers have warned that labour clauses may be merely 'rhetoric' and divert the attention of campaigners, trade unions and state officials to improve labour standards for subcontracted employees through collective action, or strengthened legal mechanisms (Freeman, 2005; Holley et al., 2015).

Empirical research on these issues has, however, so far been mainly restricted to single country (or single local authority) studies, whereas comparative assessments taking into account the wider regulatory framework remain an exception (Schulten et al., 2012; Jaehrling et al., 2015). Moreover, many studies have focused on the political struggles around the decision to either adopt or abolish labour clauses in broad terms, but there is scarce evidence on how they are designed, implemented and monitored. As a growing body of literature emphasises, the monitoring and enforcement of social policies are crucial to embed higher standards in low wage sectors (Dickens 2012; Dietz et al., 2014).

This article seeks to fill these gaps through a comparative case study of socially responsible procurement practices in the local government sector in three European cities: Copenhagen (Denmark); Bremen (Germany); and Leeds (UK). By analysing the whole policy cycle of labour clauses from initial negotiations through to implementation and monitoring, it is possible to evaluate the extent to which socially responsible procurement moves 'beyond rhetoric'. The cross-country comparative research design also allows for an assessment of the role of labour clauses in different sectoral and national systems of labour market regulation. Moreover, by choosing 'best case' procurement policies within local government but across different contexts, the article critically evaluates the circumstances under which labour clauses are both effective and sustainable.

The next section reviews recent literature on public procurement and precarious employment and discusses the potential obstacles and factors that shape the implementation of socially responsible procurement practices within different regulatory systems. The article then analyses the empirical data from the three case studies, covering the policy cycle from design to implementation and enforcement. The final section contains a discussion and the conclusions. 


\section{The dynamics of regulating working conditions in public supply chains}

The ability of public authorities at national, regional and local level to effectively regulate working conditions in outsourced services is an issue of growing importance, and underlines deep rooted tensions between the various functions of the state at different levels. The outsourcing of public services such as cleaning, school catering, and care for older people in many European countries over the last 30 years or so aligns with the dominant economic logic of introducing choice and competition into public markets, and the belief that privatisation will deliver higher quality services at a lower cost (Wollmann et al., 2016). However, the fragmentation of services combined with downward pressure on costs have contributed to various features of precarious work among the sub-contracted workforce such as low wages, on-demand and zero-hours contracts, and high levels of work intensity (e.g. Bessa et al., 2013; Brennan et al., 2012; Schulten and Schulze-Buschoff, 2015; Vrangbæk et al., 2015). This in turn places both moral and fiscal demands on the state to temper these 'negative externalities' of the market through the use of statutory minimum wages and social protection (Grimshaw et al., 2016).

A more focused solution to the problem of precarious work in public supply chains can be found in 'socially responsible procurement'. This sees specific 'labour clauses' that set improved wages and working conditions added to public contracts in order to better protect outsourced workers from precariousness. At a macro level, however, the literature points to three main obstacles to the successful re-regulation of public supply chains through the use of labour clauses.

The first (and potentially most complex) obstacle is that at the European level, the notion of 'buying social' clashes with a hegemonic interpretation of EU law giving priority to the fundamental economic freedoms laid down in the EU Treaty. This has resulted in limited scope for the inclusion of social goals in public procurement in member states (Arrowsmith and Kunzlik, 2009, p. 192) and is backed up by a restrictive jurisprudence over working conditions by the European Court of Justice. This was evidenced in the 2008 Rüffert judgment (ECJ C-346/06), which imposed narrow legal limits on pay clauses in procurement legislation and practice (McCrudden, 2011; Koukiadaki, 2014).

The second (and less investigated) obstacle is the powerful influence of employers' associations and business federations over the interpretation and implementation of EU law within member states. For example, in the UK and Ireland, Dundon et al. (2014) point to the 'capturing' by employers of the regulatory space around the 2004 Information and Consultation directives, which effectively excluded workers from joint regulation. Others argue that the gradual 'marketisation' of regulatory functions has reinforced the position of capital (MacKenzie and Martinez-Lucio, 2005), not least as processes of decision making are increasingly 'sealed off' from public scrutiny and social influence (Greer and Doellgast, 2017). Furthermore, the ambiguities surrounding procurement law and the increasing multiplicity of goals attached to public procurement may limit the ability of administrators and policymakers to prioritise one set of considerations (such as working conditions) over another (such as support for SMEs, see Arrowsmith and Kunzlik, 2009).

The final (and perhaps most practical) challenge is the continued pressure to reduce costs by outsourcing which reflects a pervasive belief among national policy-makers that the private sector is inherently more cost-efficient (Peters, 2012). The heavy pressure of fiscal austerity on local government in many European countries is likely to curtail the ambition of local councils to act in pursuit of social goals where it incurs additional costs (Grimshaw. et al., 2016). 
The factors identified above amount to a rather unfavorable setting for the implementation of marketcorrecting regulations in public procurement. Despite these challenges, labour clauses were wellestablished mechanism of regulating wages in supply chains in sectors such as construction, dating back to the $19^{\text {th }}$ century (McCrudden, 2007; Cunningham and James, 2016). What is of particular interest for the current research is how local authorities across countries with diverse systems of employment regulation have invoked labour clauses for a wider range of services such as catering, cleaning, care work, prison and probation services in challenging financial and legal conditions (Holley et al., 2015; Ludlow, 2015; Jaehrling et al., 2015; Ravenswood and Kaine, 2015). Within the EU, these attempts to reassert labour clauses operate from within the (admittedly broad) interpretation of the existing EU procurement directives (McCrudden 2011). Despite the strong influence of EU legislation, the procurement regulations and practices within countries have not simply converged into a single model (Rödl, 2009; Blauberger, 2014; Bruun and Ahlberg, 2014). This in turn means that public procurement is an increasingly politicised field, where the competing interests of public authorities, workers and private business are played out. Therefore, the agreement and implementation of labour clauses are shaped not only by the wider regulatory framework of EU law, as well as Eurozone fiscal policy conditions, but also by the peculiarities of national and sectoral employment systems and the specific power resources of actors within those systems (Jaehrling, 2015a; Cunningham and James, 2016).

Drawing on institutional accounts of labour market regulation, it is possible to identify two (stylised) interactions between labour clauses and embedded wage-setting systems that offer different potential benefits and limitations: compensatory and complementary. These two (stylised) interactions may capture not only cross-national differences, but also important variations between sectors due to the importance of sector-specific systems of industrial relations (Bechter et al., 2012).

Where labour market regulation is weak and social dialogue limited, procurement instruments potentially have a significant compensatory role in harmonising standards between the public and the private sectors (Schulten et al., 2012). For example in the UK, low union density and limited collective bargaining coverage in low-wage industries (such as cleaning and catering) mean that many subcontracted workers rely on statutory minimum wage protection. Wage clauses have been used by national public bodies in the procurement of large capital construction projects such as the 2012 London Olympics (Druker and White, 2013), but recent attention has shifted to the problem of precarious working conditions in 'core' local authority revenue contracts such as cleaning and care services. The general absence of multi-employer bargaining in the UK, and tight spending constraints in local government, mean that around 500,000 - mostly female - workers providing home care for the elderly in the private sector face low wages and contingent contracts (Bessa et al., 2013). In this context, labour clauses are increasingly seen by local authorities and trade unions as an expedient way to raise standards among the subcontracted workforce (Johnson., 2017). The problem here is that without strong underpinning mechanisms of social dialogue, localised initiatives may be difficult to 'scale up' to cover more workers in different sectors or local authority areas.

By contrast, where employment regulation is strong and social dialogue is relatively well coordinated (such as in Germany and Denmark), labour clauses may fulfil a complementary role since they offer a means to bring subcontracted workers under the reach of existing mechanisms of collective bargaining (Jaehrling, 2015a). In this context, public procurement has a broader function to engage subcontractors in regular negotiations over wage rates (as opposed to agreeing to a one-off set of contract terms), and potentially provides a framework for inspection and monitoring. This can directly 
put pressure on reluctant employers to engage, but can also lead to new coalitions between employers and unions who seek to restore the legitimacy and 'bite' of existing wage-setting systems (Blauberger, 2014). The complicating factor in this scenario is that the extent to which labour clauses complement existing mechanisms of collective bargaining may be shaped by both national and sectoral dynamics which give rise to changing patterns and concentrations of precariousness. For example, despite high union density and collective bargaining coverage in Denmark, a small, but growing minority of workers in sectors such as cleaning and construction (often migrant workers) are non-union members working in companies not complying with existing collective agreements meaning hourly pay is often below prevailing wage rates (Arnholtz and Hansen, 2013). The situation is similar in Germany where declining collective bargaining coverage outside of the 'core' manufacturing sectors combined with the absence of a national minimum wage (until 2015) mean that low wages and atypical contracts are of increasing concern (Eichhorst and Tobsch, 2015).

\section{How to make labour clauses work?}

Whether labour clauses compensate for or complement systems of labour market regulation, in and of themselves, their localised nature often means that they only cover a limited number of workers, and there is a risk that they detract from broader efforts to systematically re-regulate low wage labour markets (Freeman, 2005). There are also doubts about the ability of campaigners to maintain pressure on public bodies to prevent the dilution of labour clauses over time, and some are sceptical about the resources committed by local state actors to monitoring and enforcement: 'any expectations that government contracting agencies will monitor and enforce labour standards are misleading. At best, the clauses are rhetoric, and at worst, they are a distraction for parties with enforcement powers' (Holley et al., 2015: 43). Furthermore, since labour clauses fall outside of existing institutionalised forms of interest reconciliation between employers and employees (collective agreements) actors may struggle to effectively transfer their power resources to this increasingly important arena of negotiations and to ensure that any agreements are both binding and sustainable (Jaehrling, 2015b).

However, studies on the implementation of social procurement policies at local level have yet to reveal how actors within distinct employment systems leverage their power resources to tackle precariousness. The following fine-grained analysis of social procurement policies over the whole policy cycle (including adoption, design, monitoring, and enforcement) examines the negotiation process between social partners over these new labour market rules, and how they interact with the wider institutional context.

\section{Research and methods}

The data are drawn from a cross-national comparative study of precarious work in six EU countries which took place during 2015-16, generating a total of 21 case studies and 144 interviews with employers, unions, government officials, managers and workers. The three case studies in this article focus on the procurement of construction and cleaning in Copenhagen (Denmark), construction and catering in Bremen (Germany) and care for older people in Leeds (UK). The specific cases were sampled purposively to provide innovative examples of 'good practice' in local government procurement, thus the research design identified local councils across the three countries that had attempted to develop socially responsible procurement initiatives, before identifying specific service areas that met certain conditions critical to this investigation. The first condition to be met was that local government was a significant customer and that individual councils were responsible for managing contracts of significant value in these service areas. The second was that the service was largely procured and 'consumed' locally, thereby affording greater accessibility for local regulatory projects aimed at tackling 
precariousness. The third was that the procured service activity was characterised by cost competitive market conditions (driven both by downward pressure on public budgets and competition between providers in the private market), often resulting in poor wages and working conditions. Although not all sectors (care, cleaning, construction) were represented in each of the three municipalities, the way in which the local councils attempted to introduce labour clauses in these areas was considered potentially illustrative of the dynamics of regulating public sector supply chains where cost considerations typically dominate. Finally, the choice of three service activities followed a concern to cover both female- and male-dominated sectors (care/cleaning and construction, respectively). Overall, there are clearly differences in the size, structure and employment relations institutions across the different service areas and countries covered, which is a key factor in exploring the potential compensatory or complementary role of labour clauses.

In the three selected municipalities, labour clauses were introduced as a mechanism to close specific gaps between public and private sector wage rates, and all three could be considered 'leaders' in socially responsible procurement within local government in their respective countries. For example, 90 percent of Danish municipalities make use of non-mandatory labour clauses for some of their contracts, but Copenhagen is unusual in that it systematically includes them in all public contracts and monitors them. In Germany, 12 out of 16 federal states mandate labour clauses, but Bremen City pioneered this approach and extends it to a wider range of industries than most. Leeds is one of only 13 UK local authorities (out of 365) applying labour clauses to contracts for older persons' care, following its adoption of a voluntary 'ethical care charter' launched by one of the main local government trade unions in 2012.

The research draws on a sub-set of 28 interviews (14 in Copenhagen, eight in Bremen and six in Leeds) with key stakeholders: local government officials; politicians; trade union representatives; employers' association officials; managers from private sector subcontractors; and staff from the inspection agencies (in Bremen and Copenhagen). Interview data were triangulated with various publicly available documents such as calls for tenders, contract awards, internal documents from the municipalities, along with news coverage to explore the ongoing process of implementation and monitoring.

\section{Findings}

The research findings are organised around the different stages of the policy-making cycle, from the initiation of political discussions about the need for labour clauses, to negotiations about their design, through to the implementation and monitoring phase.

\section{Mobilising actors to address precariousness}

Across the three case-study municipalities, socially responsible procurement was supported by broad coalitions of actors, mainly trade unions and politicians, but also employers who engaged 'pragmatically' in order to address problems in the supply chain. The data suggest the mobilisation of these coalitions is far from an inevitable consequence of specific structural or institutional factors such as the gap between public and private sector wages or weaknesses in systems of employment relations, , but are the product of a complex contextual and relational dynamics .

A first key dimension of mobilisation involved the strong relationships between centre-left political parties and locally recognised trade unions. All three municipalities were dominated by Social Democratic/Labour political parties, which advanced labour clauses as part of a broader 'social' agenda. In Copenhagen, for example, labour clauses were an important issue in the 2013 local government election. Nevertheless, in all cases the unions leveraged their traditional connections to lobby local politicians. In Bremen this was bolstered by the fact that two Social Democrat politicians 
were previously trade unionists at the local level. In Leeds, Labour party politicians and commissioners argued that the council had longstanding ambitions to improve care services for the elderly, but for the union locally, persuading the council to agree to specific labour clauses was the result of three years of persistent lobbying: '... we kept banging on about ethical care, banging on about travelling time, banging on about zero hour contracts... in the end I think they just got fed up with us...' (Leeds union representative).

Secondly, the mobilisation of active coalitions also required trade unions to move beyond a longstanding reliance on a voluntarist wage-setting system and seek alternative mechanisms of regulating outsourced work. While the union in Leeds was unequivocal about the positive role for labour clauses, the Danish unions were more hesitant. Although most Danish unions have long pressed local, regional and central government to formally adopt labour clauses, parts of the union movement shared many employers' critical stance towards labour clauses - especially concerning chain liability. This scepticism was due to the potential threat to the strongly voluntarist Danish system of collective bargaining. Some trade unionists and most employers were concerned this would enable policymakers to introduce more labour law, not least a statutory minimum wage, 'through the backdoor'. By contrast in Germany, the widely observed failure of the voluntarist system to secure minimum standards in large swathes of the economy had overturned views among trade unions and the Social Democratic party and encouraged them to join lobbying activities by the service sector union (since 1999) for a national minimum wage (Bosch and Weinkopf, 2017). In this situation, the local Social Democratic Party's support to extend pay clauses to public grants in 2012 was also motivated by the strategic objective of supporting a new statutory minimum wage, as the then chair of the governing Social Democratic Party (SPD) explained:

"We decided to do that in order to set down markers, in order to say (...): it's possible. There are realms where the State can say, "I insist on a minimum wage, end of story'. (...) So we decided to set down this milestone, and thereby also send a signal to the minimum wage debate at the national level" (SPD member of state parliament, authors' translation)

Finally, the general public discourse and media attention also stimulated support for labour clauses, not least for their symbolic role and signalling effect in all three municipalities. In Copenhagen, media attention to precarious working conditions facing foreign employees in cleaning propelled the issue of labour clauses high up the agenda. In Germany, the deliberate focus of left-wing opposition parties ('Die Linke') on cases of negative experiences with outsourcing helps explain a general turn towards a 'socialpolitization' of procurement policies (Sack and Sarter, 2016). Similarly, in the UK, high profile media attention to living wage campaigns and problems of unpaid travel time and zero hours contracts among subcontracted cleaning and care workers have firmly placed labour clauses on local authority agendas (Koukiadaki, 2014).

\section{Negotiating the scope and coverage of labour clauses}

The fact that supportive political coalitions emerged to adopt labour clauses did not prevent conflicts from emerging in their design. There were substantial variations among the three case studies (table 1), reflecting the difficulties in balancing the vested interests of employers and unions, but also the downward pressure on municipal budgets which made compromises inevitable.

[TABLE 1 here]

The labour clauses in Copenhagen were the most comprehensive as they extended existing collectively agreed wages and working conditions to subcontracted workers. Furthermore, the addition of labour 
clauses to contracts gave them a legally binding status (whether or not employers formally signed the most representative collective agreement). Furthermore, the decision of Copenhagen council to strengthen the rules around chain liability to cover successive tiers of subcontractors in all forms of outsourced work was welcomed by the unions, but opposed by the employers and the liberal parties who argued this could potentially violate EU legislation. In a different regional authority, the Danish construction employers' association tested the legality of chain liability by bringing a case before the public procurement complaint board, but lost the case. By contrast, Danish employers were successful in blocking the proposal of low-skill workers' unions to exclude firms not covered by collective agreements from public tenders.

In Bremen, labour clauses effectively reinforce minimum wages set by collective agreement in industries such as construction and cleaning. In that sense they may seem 'unnecessary' (Holley et al., 2015), but our data demonstrate that pay clauses have an important signalling effect in respect of the legitimacy of collectively agreed wages, and also establish an 'anchor' for monitoring and enforcement. However, the labour clauses in Bremen were less comprehensive than in Copenhagen as they stipulated compliance with the lowest (skilled and unskilled) pay grades only and excluded other working conditions. In addition, a local minimum wage was introduced in 2009 for all other industries in order to compensate for the absence of a national minimum wage or industry specific minimum wages. At $€ 8.80$ per hour, this was only slightly above the national minimum wage introduced in 2015 and so was abandoned in 2016. At this point Bremen reverted to the minimum rates agreed in the 'most representative' collective agreement in the construction sector but only for tenders below the EU thresholds for works $(€ 5.225 \mathrm{~m})$. Interestingly, the decision to return to pre-Rüffert pay clauses for construction services was mainly initiated on the request of local employers covered by the construction collective agreement. They argued that they would be dis-incentivised to commit themselves to collectively agreed wages if their competitors were only bound by an industry specific minimum wage. Thus, from 2016 onwards labour clauses in construction were made even more 'complementary' as they more fully transposed existing collectively agreed wage standards into contracts. However, the success in the construction sector (which historically was well-organised and male-dominated), did not spill-over into female-dominated industries such as school catering and social services, where both employers and unions are less powerful. Claims voiced by the trade union of the catering sector (NGG) and the 'left' opposition party to maintain the procurement specific local minimum wage and lift it to a level corresponding to the lowest level of the public sector collective agreement were unsuccessful. Furthermore, unlike in the Leeds case, in Bremen, the policy initiative did not explicitly increase the budget for public contracts which meant that in practice, commissioners were still incentivised to choose the contract with the lowest price (and implicitly accept that outsourced workers would receive low wages).

The use of labour clauses in contracts for care services in Leeds was ambitious by UK standards: setting increased basic hourly wages; guaranteeing payment for travel time between clients (which under the old contract was unpaid 'slack time'); and replacing contingent zero-hours contracts with guaranteed hours contracts (full- and part-time). Although a national collective agreement covers directly employed care workers in UK local government, labour clauses clearly played a strong compensatory role for subcontracted workers many of whom work in private sector firms that do not recognise a trade union. At the same time, low wages in private sector care work are not just a function of gaps in collective bargaining or employer avoidance strategies: they are fundamentally driven by downward pressure on unit costs in public contracts (Bessa et al., 2013). Leeds council recognised that to tackle low wages and precarious work, resources had to be increased to cover the cost of higher hourly rates and travel time, and the number of providers had to be reduced (from nearly fifty to just four) in order 
to stabilise contract volumes and allow providers to offer guaranteed hours contracts to workers). While some of the larger national private sector care 'chains' who lost the contract tried to 'bully' the council by lodging appeals, there was strong support from smaller private care providers for public procurement being used in this way to 'level the playing field'.

\section{Monitoring and enforcement}

Developing adequate administrative capacity through sufficient budgets, trained staff, and rights of inspection is pivotal when considering the ability of political and administrative decision-makers to monitor procurement in line with their own objectives, as emphasised in studies on public-private partnerships (e.g. Hodge and Greve, 2005). However, this is not merely a 'technical' question about developing effective tools, but reflects various political and power struggles within different institutional frameworks. Our data highlight significant variation between the three cases in terms of the involvement of social partners in developing monitoring and enforcement systems, as well as the resources allocated to monitoring and enforcement, the use of internal or external inspectors, the form and frequency of inspections, and penalties for non-compliance.

Copenhagen had a substantial dedicated budget for monitoring and enforcing the labour clauses, and was until early 2017 the only Danish municipality that delegated the monitoring of labour clauses to an independent auditing company. Subsequently the council brought enforcement back in-house, in order to strengthen relations between the procurement unit, inspectors and subcontractors. Similar as before inspection units consisted of four to five full-time employees, that carried out on-site inspections and had the delegated authority to demand relevant documentation from subcontractor companies such as wage slips, employment contracts, over-time payments, accrued pensions and holiday remuneration. The inspections covered all subcontracting firms but targeted those companies considered at high risk of non-compliance (such as those employing large numbers of migrant and lowskilled workers). This framework of extended controls was initially questioned by the employers and was opposed by the conservative and liberal parties as unnecessary 'red tape', but was welcomed by the unions. Between autumn 2014 and late 2016, the external auditors carried out 2,026 inspections, mainly targeting construction subcontractors, and around one in 20 inspections (six percent) identified minor breaches, which reportedly were often due to misunderstandings or misinterpretation than deliberate attempts to bypass the system. In cases of suspected non-compliance, the commissioning authority has the power to impose sanctions, but most cases of general non-compliance are solved through negotiations between the partners involved, and specific breaches may result in the payment of any outstanding salaries or remuneration (typically overtime payments and holiday remuneration). Only in a few instances did the municipality decide to terminate or not renew contracts. In this sense, although monitoring and enforcement was a key feature of the Copenhagen case, it can be argued that in the Danish context of strong social dialogue and voluntarism labour clauses have a largely preventive rather than a corrective effect (Bådsgaard and Jørgensen, 2016).

The way Bremen monitors labour clauses shares some similarities, but also important differences to Copenhagen. An internal inspectorate within the municipality's Department of Economic affairs selects firms for inspection and monitors the inspections, while the actual inspections are carried out by other agencies (either law firms or a public service company owned by the local authority). However, compared to Copenhagen, Bremen has allocated very few specific additional administrative resources for monitoring the inspections which are often conducted by just one employee of the public service company within a rather restricted time frame. It seems that the lack of adequate financial and administrative resources for monitoring the labour clauses in Bremen creates discrepancies between the objectives of the labour clauses and their enforcement, such that the labour clauses risk being 
merely a policy document of intent rather than an effective tool to combat precarious employment. Between 2013 and 2015116 inspections were carried out and sanctions imposed in 19 cases. In most cases, sanctions included penalties of less than $€ 10.000$, and the companies were excluded from public tenders for a period of between six and 15 months. In contrast to Copenhagen, both the unions' and employers' representatives were sceptical of strong preventative effects of labour clauses, owing to the lack of additional funds allocated to public contracts. The unions also criticised the limited resources allocated for inspections, and called for a shorter time period for private sector subcontractors to deliver the requested documentation in case of non-compliance to reduce fraud with payslips.

In Leeds, the local authority has pursued a somewhat different enforcement approach. Unlike Copenhagen and Bremen, the Leeds council opted for a 'price-fixing' approach to ensure that contract values reflected the true costs of service provision (of which labour costs were the largest component), instead of merely mandating wage levels to be met out of existing resources allocation. . The introduction of more resources for the contracts themselves was expected to encourage the market to 'self-regulate': providers would have fewer incentives to evade the rules and undercut on labour costs. The problem, however, is that by reducing the number of providers from fifty to four the municipality now has fewer options for alternative provision in the event that there was evidence of substandard provision. Leeds retained the monitoring and enforcement of the labour clauses in-house, but unlike Bremen and Copenhagen had no specific budget or administrative resources to inspect subcontractors' wages and working conditions. Although procurement managers were keen to promote compliance with the higher standards, this was handled through 'soft' regulation in the form of regular meetings with providers rather than 'hard' regulation through inspection and audit. Furthermore, although the local union official was hopeful that the labour clauses would facilitate the collective organisation of subcontracted workers, a lack of progress on formal union recognition with private subcontractors meant that labour clauses had not translated into voluntarist mechanisms of wage setting which went beyond just the Leeds care contract.

\section{Discussion and Conclusion}

The spread of precarious work in public sector supply chains has given rise to new policies aimed at establishing and enforcing labour standards for the subcontracted workforce, including the most vulnerable groups such as migrant workers and women in low-paid service jobs. Three key findings are highlighted in the discussion of our findings.

Firstly, the findings from all three cases underline the importance of pragmatic alliances of progressive politicians, unions, and employers at local level to challenge the hegemony of economic goals enshrined in EU procurement law and national austerity policies. The formation of these coalitions is somewhat unexpected, given the different obstacles at the macro-level to market embedding (procurement) policies identified in the literature (restrictive European law; increasing influence of employers in the context of marketisation, national austerity goals and tight public budgets). Our analysis suggests that changes in the labour market (the rise in low-wage competition and precariousness in public supply chains) and gaps in systems of regulation may have been a necessary, but not sufficient condition for socially responsible procurement to emerge. Rather, genuine efforts to combat precariousness seem to hinge substantially on the political dynamics at local level. The successful introduction of labour clauses required substantial mobilisation efforts from the trade unions to lobby 'left wing' political parties and to dispel any residual concerns (among both politicians and partly also the trade union camp itself) about the threat of labour clauses to voluntarist systems 
of wage setting, supported by a favourable public discourse and media attention. Unlike the 'crossclass coalitions' identified by Palier and Thelen (2010), which contribute to a further dualisation in employment standards, the coalitions in this study actively reached out to those on the margins, in particular low-paid women and migrant workers. In this way, labour clauses have the potential to serve the interests of both those at the core and at the margins of the labour market. This 'voluntarist' explanation of labour clauses, which established higher standards for precarious workers, demonstrates the scope for political impact at the local level.

Secondly, the data confirms that effectively regulating public supply chains requires more than simply fixing standards on paper; much depends on the monitoring and enforcement process. What is novel is that all three councils in this study have made specific provisions to try and ensure that the labour clauses are observed by subcontractors in practice, albeit using different methods and with different degrees of success. For example Copenhagen has set aside additional resources for inspection and enforcement and uses an external auditor to check that the labour clauses are being observed (which in most cases they are), whereas Bremen relies on a relatively small inspection function with no additional resources from the local council which has raised concerns among the unions that firms are able to evade labour clauses. In both cases, the delegation of decisions over contract values to commissioners still means that cost considerations are salient when awarding contracts (particularly where budget pressures are acute). In contrast, the conscious decision in Leeds to substantially uplift the contract values for care services is designed to directly enable subcontractors to meet the additional cost of increased wages and payment for travel time with fewer requirements on the council to actively monitor and enforce. The trade-off here is that there are relatively few mechanisms to identify and quickly act upon 'breaches'. Therefore, the introduction of labour clauses has not 'resolved' the tensions between the dual role of local government as regulator and client, but our data show that this tension extends beyond the initial agreement of labour clauses to the process of implementation and enforcement. For instance, the Danish employers successfully blocked the proposal of the unions to pre-emptively exclude firms that have not signed the sector collective agreement from bidding for public contracts. This and other conflicts, e.g. about the resources to be devoted to inspections, or the issue of chain liability, underline the need for analyses covering the full policy cycle.

Thirdly, with regard to the impact of labour clauses in different institutional contexts, all three initiatives make a difference compared to the status quo ante. However, our analysis differentiates between more narrowly defined labour clauses which 'compensate' for weak systems of regulation by providing a new set of minimum standards for outsourced workers in Leeds and catering services in Bremen, and a broader levelling up effect of labour clauses in Copenhagen (construction and cleaning) and construction in Bremen, which 'complement' underlying systems of joint regulation between social partners by bringing firms and workers within the scope of existing collectively agreed wage standards. In the 'complementary' settings, labour clauses are able to extend prevailing rates of pay (and some additional benefits) to a growing minority of workers who are de facto not already covered, without undermining the existing regulatory system. In contrast, labour clauses in the 'compensatory' examples raise wages for a large share of subcontracted employees, thereby filling a crucial gap in systems of regulation. However the raising of wages starts from a relatively low level (when compared with the collectively agreed wages in the complementary settings), and the reliance on labour clauses has not reinvigorated wider systems of voluntarist wage setting.

There are, however, important limitations in terms of the generalisability of our findings, which are linked to the purposive sampling of 'best' or potentially paradigmatic cases from varied national and sectoral systems of labour market regulation. The three case studies were not chosen for their 
representativeness, but specifically because they had moved furthest towards the systematic adoption, implementation, and enforcement of labour clauses for local government contracts within their national and sectoral contexts. The cases illustrate that the effective regulation of public supply chains is not necessarily determined by specific institutional factors such as the size of public budgets, the gaps between public and private sector wage rates or even the prevailing industrial relations systems, but is a product of deliberate political choices. Our data show that Labour and Social Democratic politicians were at the forefront of socially responsible procurement, which contradicts Rueda's (2014) criticism of the supposed insider-bias of left wing political parties. However, sympathetic politicians may not automatically push for such socially oriented projects, especially when faced with tight budget constraints, without pressure from trade unions, local media and to a lesser extent employers who are concerned about unfair wage competition. These important contextual factors also underline the potential vulnerability of these coalitions and localised agreements in the face of changing political and financial winds.

Furthermore, there remain clear tensions between labour clauses and the wider institutional framework that might additionally limit the spread of these best practices. Although socially responsible procurement can compensate for weak or absent mechanisms of collective bargaining as observed in the care sector in Leeds, it requires crucially additional resources for external contracts (which may not be feasible at all local councils). In contrast the ability to tackle precariousness is certainly strengthened where socially responsible procurement policies complement existing mechanisms of collective bargaining and labour market regulation as observed in construction and cleaning in Copenhagen and in the construction sector in Bremen. The problem is that the potential complementary role hinges on sectoral as well as national systems of employment regulation. While the adoption of labour clauses spans both construction and cleaning in Copenhagen, the relative weakness of the trade unions in the catering sector in Bremen (compared with construction) and a less coordinated political lobby mean that these largely female workers are not any longer covered by labour clauses which leaves them doubly disadvantaged by weak systems of joint regulation and an absence of quasi-legal protections in the form of labour clauses.

Nevertheless, we do not share the scepticism of Freeman (2005) or Holley et al. (2015) that labour clauses are a distraction from wider efforts to re-regulate low wage labour markets; they can play an important role in both fragmented and coordinated systems of employment relations. This is achieved by directly improving pay and working conditions for groups of workers most at risk of experiencing precariousness, while also providing a potential 'lighthouse effect' for other local and regional councils to pursue similar strategies of socially responsible procurement. The three examples of the successful adoption of labour clauses in this research somewhat 'against the odds' give hope to future efforts to tackle precariousness across diverse national and sectoral contexts. At the same time, they also illustrate that socially responsible procurement requires more than fixing standards on paper; significant efforts are required from all parties to embed decent working conditions as a core principle of public contracting.

\section{Acknowledgement / Funding}

This article draws on results from a European Commission funded project (DG Employment, Social Affairs and Equal Opportunities VP/2014/004, Industrial Relations \& Social Dialogue) on reducing precarious work: protective gaps and the role of social dialogue coordinated by Damian Grimshaw. We are grateful to the European Commission for the funding. 


\section{Notes}

\footnotetext{
${ }^{1}$ As defined by the International Labour Organisation convention No. 94, a labour clause in public procurement requires subcontractors to meet prescribed social and labour standards in bids for public contracts, with the aim of upholding the best locally established working conditions.
}

\section{References}

Arnholtz, J. and Hansen, N. (2013) 'Labour market specific institutions and the working conditions of labour migrants', Economic and Industrial democracy 34(3): 1-22.

Arrowsmith, S. and Kunzlik, P., eds. (2009) Social and environmental policies in EC procurement law. New directives and new directions. Cambridge: Cambridge University Press.

Bådsgaard, K. and Jørgensen, H. (2016) Københavns Kommunes indsats mod social dumpingmålopfyldelsesevaluering. Aalborg: Aalborg Universitet, Carma.

Bechter, B., Brandl, B. and Meardi, G. (2012) 'Sectors or countries? Typologies and levels of analysis in comparative industrial relations', European Journal of Industrial Relations 18 (3): 185-202.

Bessa, I., Forde, C., Moore, S. and Stuart, M. (2013) The National Minimum Wage, earnings and hours in the domiciliary care sector. University of Leeds and Low Pay Commission, London.

Blauberger, M. (2014) 'National Responses to European Court Jurisprudence', West European Politics, 37 (3): 457-474.

Bosch, G. and Weinkopf, C. (2017) 'Reducing wage inequality: The role of the state in improving job quality', Work and Occupations 44 (1): 68-88.

Brennan, D., Cass, B., Himmelweit, S. and Szebehely, M. (2012) 'The marketisation of care: Rationales and consequences in Nordic and liberal care regimes', Journal of European Social Policy 22(4): 377-391.

Bruun, N. and Ahlberg, K. (2014) Public Procurement and Labour Rights: Governance by Scaremongering? In: Evju S (ed.) Regulating Transnational Labour in Europe : The quandaries of multilevel governance. Skriftserie / University of Oslo. Department of Private Law, Oslo: Privatrettsfondet, 263-279.

Cunningham, I. and James, P. (2009) 'The Outsourcing of Social Care in Britain: What Does it Mean for Voluntary Sector Workers?', Work, Employment and Society 23(2): 363-375.

Cunningham, I. and James, P. (2016) 'Analysing public service outsourcing: The value of a regulatory perspective', Environment and Planning C: Politics and Space 35 (6): 958-974

Dickens, L. (2012) (ed.) Making employment rights effective: Issues of enforcement and compliance. Oxford [u.a.]: Hart Publishing.

Dietz, M., Levitt, D. and Love, E. (2014) 'Enforcement of Labor Standards', in: Reich, M., Jacobs, K. and Dietz, M. (eds.) When Mandates Work: Raising Labor Standards at the Local Level. Berkeley [u.a.]: University of California Press, pp. 229-255.

Druker, J. and White, G. (2013) 'Employment relations on major construction projects: The London 2012 Olympic construction site', Industrial Relations Journal 44 (5-6): 566-83.

Dundon, T., Dobbins, T., Cullinane, N., Hickland, E. and Donaghey, J. (2014) 'Employer occupation of regulatory space of the Employee Information and Consultation (I\&C) Directive in liberal market economies', Work, employment and society 28(1): 21-39.

Eichhorst, W. and Tobsch, V. (2015) 'Not so standard anymore? Employment duality in Germany', Journal for Labour Market Research 48 (2): 81-95.

Freeman, R. (2005) 'Fighting for Other Folks' Wages: The Logic and Illogic of Living Wage Campaigns', Industrial Relations 44 (1): 14-31. 
Grandia, J. and Meehan, J. (2017) 'Public Procurement as a Policy Tool:Using procurement to reach desired outcomes in society', International Journal of Public Sector Management. 30 (4): 302309.

Greer, I. and Doellgast, V. (2017) 'Marketization, inequality, and institutional change: Toward a new framework for comparative employment relations', Journal of Industrial Relations 59 (2): 192208.

Grimshaw, D., Rubery, J., Anxo, D., Bacache-Beauvallet, M., Neumann, L. and Weinkopf, C. (2015) 'Outsourcing of public services in Europe and segmentation effects: the influence of labour market factors', European Journal of Industrial Relations 21(4): 295-313.

Grimshaw, D., Johnson, M., Rubery, J. and Keizer, A. (2016) Reducing precarious work-protective gaps and the role of social dialogue in Europe. Report for the European Commission DG Employment. Available at: http://www.research.mbs.ac.uk/ewerc/Our-research/Current-projects/ReducingPrecarious-Work-in-Europe-through-Social.

Hermann, C. and Flecker, J., eds. (2012) Privatization of Public Services: Impacts for Employment, Working Conditions, and Service Quality in Europe. London: Routledge.

Hodge, G. and Greve, C. (2005) The challenge of public-private partnerships: Learning from international experience. Cheltenham, UK, Northampton, Mass: Edward Elgar.

Howell, C. (2016) 'Regulating class in the neoliberal era: the role of the state in the restructuring of work and employment relations', Work, employment and society, 30(4): 573-589.

Holley, S., Machonachie, G. and Goodwin, M. (2015) 'Government procurement contracts and labour standards enforcement: Rhetoric, duplication and distraction?', Economic and Labour Relations Review 26 (1): 43-59.

Jaehrling, K. (2015a) 'The state as a 'socially responsible customer'? Public procurement between market-making and market-embedding', European Journal of Industrial Relations 21(2): 149-164

Jaehrling, K. (2015b) ,Öffentliche Auftragsvergabe - eine neue Arena der industriellen Beziehungen? Konzeptionelle Überlegungen und erste empirische Befunde', Industrielle Beziehungen 22(3-4): 325-344

Jaehrling, K., Finnestrand, H., Kirov, V. and Torvatn, H. (2015) 'The (in)visible third party: De- and reregulation of working conditions through public procurement', in: Holtgrewe, U., Kirov, V. and Ramioul, M. (eds.) Hard work in new jobs. The quality of work and life in European Growth sectors. Basingstoke: Palgrave Macmillian, pp. 130-148

Johnson, M. (2017) ,Implementing the living wage in UK local government', Employee Relations 39(6): 840-849.

Keulemans, S. and Van de Walle, S. (2017) 'Cost-effectiveness, domestic favouritism and sustainability in public procurement: A comparative study of public preferences', International Journal of Public Sector Management 30 (4): 328-341.

Koukiadaki, A. (2014) 'The far-reaching implications of the Laval Quartet: the case of the UK living wage', Industrial Law Journal 43 (2): 91-121.

Ludlow, A. (2015) Privatising Public Prisons: Labour Law and the Public Procurement Process, Oxford: Hart Publishing.

Mackenzie, R. and Martinez Lucio, M. (2005) 'The realities of regulatory change: Beyond the fetish of deregulation', Sociology 39 (3): 499-517.

McCrudden, C. (2007) Buying social justice. Oxford: Oxford University Press. 
McCrudden, C. (2011) 'The Rüffert Case and Public Procurement', in: Cremona, M. (ed.) Market integration and public services in the European Union. Oxford: Oxford University Press, pp 117148.

Palier, B. and Thelen, K. (2010) 'Institutionalizing Dualism: Complementarities and Change in France and Germany', Politics and Society 38 (2): 119-148.

Peters, J. (2012) 'Neoliberal convergence in North America and Western Europe: Fiscal austerity, privatization, and public sector reform', Review of International Political Economy 19 (2): 208235.

Ravenswood, K. and Kaine, S. (2015) 'The role of government in influencing labour conditions through the procurement of services: Some political challenges', Journal of Industrial Relations 57(4): 544-562.

Rödl, F. (2009) 'The ECJ's Rüffert-judgement: a case for "undistorted" wage competition', Harvard European Law Working Paper 01/2009. Cambridge.

Rueda, D. (2014) 'Dualization, Crisis and the Welfare State', Socio-Economic Review 12 (2): 381-407.

Sack, D. and Sarter, K. (2016): 'Der Europäische Gerichtshof und die deutschen Bundesländer Sozialpolitisierung und Rechtsunsicherheit im europäisierten Föderalismus', in: Rehder, B. and Schneider, I. (eds.) Gerichtsverbünde, Grundrechte und Politikfelder in Europa. Baden-Baden: Nomos, pp. 343-366.

Schulten, T. and Schulze-Buschoff, K. (2015) 'Sector-level strategies against precarious employment in Germany: Evidence from construction, commercial cleaning, hospitals and temporary agency work'. WSI-Diskussionspapier No. 197. Düsseldorf: WSI.

Schulten, T., Alsos, K., Burgess, P. and Pedersen, K. (2012) Pay and other social clauses in European public procurement. Düsseldorf: WSI.

Vrangbæk K, Petersen O and Hjelmar U (2015) Is contracting out good or bad for employees? A review of international experience, Review of Public Personnel Administration 35(1): 3-23.

Wills, J. (2008) 'Making Class Politics Possible: Organizing Contract Cleaners in London', International Journal of Urban and Regional Research 32 (2): 305-323.

Wollmann, H., Kopric, I. and Marcou, G. (eds.) (2016) Public and Social Services in Europe: From Public and Municipal to Private Sector Provision. Basingstoke: Palgrave.

\section{Author biographies}

Karen Jaehrling works as a senior researcher at the Institute for Work, Skills and Training (Institut Arbeit und Qualifikation), University of Duisburg-Essen, Germany. Her main research interests include issues in the area of sociology of work, labour market and social policy, with a particular focus on the lowpay / low-skilled segments of the labour market. A recent publication includes 'The atypical and gendered 'employment miracle' in Germany', In A Piasna, M Myant (eds), Myths of employment deregulation, Brussels 2017. Research in 2017 included a Horizon2020 project on the interrelationship between innovation and job quality (quinne.eu).

Mathew Johnson is a research associate at the European Work and Employment Research Centre at Alliance Manchester Business School University of Manchester. His research interests include public sector pay, living wages and trade union responses to precarious work. A recent publication includes: Grimshaw, D., Johnson, M., Marino, S., \& Rubery, J. (2016). Towards more disorganised decentralization?: Collective bargaining in the public sector under pay restraint. Industrial Relations Journal. 
Trine P. Larsen is an Associate Professor at the Employment Relations Research Center, at the University of Copenhagen. Her research interests include precarious employment, collective bargaining, social partners responses to labour market segmentation, work-life balance and equal pay. Recent published work include : Larsen T. P. and Navrbjerg, S. E. (2017) Bargaining for equal pay and work-life balance in Danish companies- Does Gender matter, published in Journal of Industrial Relations; Ilsøe, A, Larsen, T.P and Felbo-Kolding J. (2017) Living hours under Pressure- Flexibility loopholes in the Danish bargaining model published in Employee relations.

Bjarke Refslund is post.doctoral researcher at Section for Sustainable Production, Department of Materials and Production at Aalborg University, Copenhagen. His main research areas include precarious employment, work organisation, unions, labour migration as well as occupational health and safety. Recently published work include: Islands in the stream? Challenges and resilience of the Danish industrial relations model in a liberalising world in Industrial Relations Journal (2016, with Ole Henning Sørensen) and Understanding the diverging trajectories of slaughterhouse work in Denmark and Germany: A power resource approach in European Journal of Industrial Relations (2016 with Ines Wagner).

Damian Grimshaw is Director of the Research Department at the International Labour Organisation, Geneva Office. He researches international low-wage labour markets, gender equality in employment, and human resource management in the networked organisation. Recent publications include Making Work more Equal (2017, Manchester University Press), Reducing Precarious Work: Protective Gaps and the Role of Social Dialogue in Europe (2016, Report for the European Commission) and Minimum Wages, Pay Equity and Comparative Industrial Relations (2013, Routledge).. 
Tables

Table 1 - the form, level and coverage of labour clauses across the three cases

\begin{tabular}{|c|c|c|}
\hline Bremen & Copenhagen & Leeds \\
\hline \multicolumn{3}{|c|}{ Levels of protection } \\
\hline $\begin{array}{l}\text { Collectively agreed minimum } \\
\text { wage rates declared generally } \\
\text { binding } \\
\text { Procurement specific regional } \\
\text { minimum wage (2009-2016) } \\
\text { 'most representative' collective } \\
\text { agreement in construction + } \\
\text { public transport (since 2016), but } \\
\text { only in cases of restricted } \\
\text { tenders/direct awards }\end{array}$ & $\begin{array}{l}\text { Employers have to abide by } \\
\text { 'most representative' collective } \\
\text { agreement in each industry (conf. } \\
\text { to ILO conv. 94, §1); covers pay } \\
\text { and non-pay terms and } \\
\text { conditions at all levels of job } \\
\text { grade }\end{array}$ & $\begin{array}{c}\text { Higher wage rate } \\
\text { pay for travel times } \\
\text { Replacement of zero hour } \\
\text { contracts with full-or part-time } \\
\text { positions }\end{array}$ \\
\hline \multicolumn{3}{|c|}{ Coverage } \\
\hline $\begin{array}{l}\text { Universally applied in public } \\
\text { procured work }\end{array}$ & $\begin{array}{l}\text { Universally applied in public } \\
\text { procured work }\end{array}$ & Social care for elderly \\
\hline \multicolumn{3}{|c|}{ Chain liability } \\
\hline Apply chain liability & Apply chain liability & No subcontractors allowed \\
\hline
\end{tabular}


DuEPublico

Duisburg-Essen Publications online
UNIVERSITÄT

DE S S S S $S_{N}$ U R G

offen im Denken

\begin{tabular}{l|l} 
universitäts \\
bibliothek
\end{tabular}

This text is made available via DuEPublico, the institutional repository of the University of DuisburgEssen. This version may eventually differ from another version distributed by a commercial publisher.

DOI: $\quad 10.1177 / 0950017018758216$

URN: urn:nbn:de:hbz:464-20191002-145855-4

This is a pre-copyedited, author-produced PDF of an article accepted for publication that was finally published in:

Work, Employment and Society 2018, Vol 32 (3), 546-563.

Alle rights reserved. 